\title{
The chemistry and toxicity of discharge waters from copper mine tailing impoundment in the valley of the Apuseni Mountains in Romania
}

\author{
Piotr Rzymski $^{1}$ - Piotr Klimaszyk ${ }^{2}$ - Wlodzimierz Marszelewski ${ }^{3}$ - Dariusz Borowiak ${ }^{4}$. \\ Mirosław Mleczek ${ }^{5} \cdot$ Kamil Nowiński $^{4} \cdot$ Bożena Pius $^{1} \cdot$ Przemysław Niedzielski $^{6}$. \\ Barbara Poniedziałek ${ }^{1}$
}

Received: 17 January 2017 / Accepted: 19 July 2017 / Published online: 25 July 2017

(C) The Author(s) 2017. This article is an open access publication

\begin{abstract}
Copper mining generates large quantities of waste, tailings, and acid outflows causing long-term environmental impacts and potential threats to human health. Valea Sesei is the largest tailing impoundment in Romania, created by flooding the valley (known as Valea Sesei) of the Metalliferous Mountains (a division of the Apuseni Mountains) with copper mining waste. The present study (i) estimated the total volume of tailings in this area; (ii) screened the concentration of 65 elements (rare earth and platinum group elements, alkali metals and alkali earth metals, transition and post-transition metals and metalloids) and cyanide concentrations in wastewater samples collected from tailing impoundment; (iii) evaluated the toxicity of these water samples using five in vitro bioassays employing human cells
\end{abstract}

Responsible editor: Boqiang Qin

Electronic supplementary material The online version of this article (doi:10.1007/s11356-017-9782-y) contains supplementary material, which is available to authorized users.

Piotr Rzymski

rzymskipiotr@ump.edu.pl

1 Department of Environmental Medicine, Poznan University of Medical Sciences, Poznań, Poland

2 Department of Water Protection, Faculty of Biology, Adam Mickiewicz University, Poznań, Poland

3 Department of Hydrology and Water Management, Nicolaus Copernicus University, Torun, Poland

4 Department of Limnology, University of Gdańsk, Gdańsk, Poland

5 Department of Chemistry, Poznan University of Life Sciences, Poznań, Poland

6 Department of Analytical Chemistry, Faculty of Chemistry, Adam Mickiewicz University, Poznań, Poland isolated from healthy donors and a short-term $(1 \mathrm{~h})$ exposure model. The sampled waters were highly acidic $(\mathrm{pH} 2.1-4.9)$ and had high electrical conductivity $\left(280-1561 \mathrm{mS} \mathrm{cm}^{-1}\right)$. No cyanides were detected in any sample. Water samples collected from the stream (AMD) inflowing to the tailing impoundment were characterized by the greatest concentrations of alkali metals, alkaline earth metals, transition and post-transition metals, metalloids, rare earth elements, and noble metal group. At other sites, the elemental concentrations were lower but remained high enough to pose a relevant risk. The greatest magnitude of in vitro toxic effects was induced by AMD. Observed alterations included redox imbalance in human neutrophils followed by lipid peroxidation and decreased cell survival, significant aggregation of red blood cells, and increased prothrombin time. The study highlights that Valea Șesei is a large sink for toxic elements, posing environmental and health risks, and requiring action to prevent further release of chemicals and to initiate restoration of the area.

Keywords Copper mining · In vitro toxicity $\cdot$ Health risks · Tailings $\cdot$ Elemental composition

\section{Introduction}

Copper $(\mathrm{Cu})$ is one of the most economically important metals with demand expected to significantly increase by 2050 (Elshkaki et al. 2016). Its mining has a significant environmental impact as it is mostly conducted in open pits and generates large quantities of waste. Production of $1 \mathrm{t}$ of $\mathrm{Cu}$ typically requires over $150 \mathrm{t}$ of ore to be excavated, crushed, concentrated by froth flotation, and then extracted using different methods depending on the sulfide or non-sulfide nature of the ore (Wills and Napier-Munn 2006). The whole process 
produces large amounts of tailings, which are the residues of the ore remaining after $\mathrm{Cu}$ extraction and contain high levels of toxic metals (e.g., $\mathrm{Cd}, \mathrm{Fe}, \mathrm{Pb}, \mathrm{Zn}$ ) and metalloids (e.g., As) (Courtney 2013; Wang et al. 2016). Additionally, outflows from mines, known as acid mine drainage, contribute to the allocation of toxic elements dissolved from rocks overrun by water characterized by extremely low $\mathrm{pH}$, primarily due to oxidation of iron sulfide (Akcil and Koldas 2006).

The key issues in decreasing the impact of mining on environmental and human health include (i) mitigation of acid mine drainage effects by preventing oxidation, neutralizing the acid, or collecting the runoff (Akcil and Koldas 2006) and (ii) appropriate management and disposal of tailings (Mleczek et al. 2016). Most conventional impoundment methods involve the construction of surface ponds with raised embankments in which tailings and mine water are systematically deposited downstream, upstream, or centerline (Vick 1990), although methods such as sub-marine disposal or disposal of dewatered tailings as backfill are also in use (Berkun 2005; Fall et al. 2010). Tightened legislation and increased public awareness have forced mine operators to reinforce the stability of embankments and dams, and monitor the process of disposal (Dold 2008). Otherwise, a dam failure and subsequent release of great quantities of waste may cause an environmental disaster and large-scale health threat - a number of such events have already occurred in mining history (Rico et al. 2008).

In some of locations, tailings are still deposited on natural surfaces without raised embankments. One of the most striking examples of this is Valea Şesei, the largest tailing impoundment located in the Apuseni Mountains in Romania (Milu et al.2002). It was created as a consequence of the open pit Rosia Poieni $\mathrm{Cu}$ ore exploitation initiated in 1986 and encompasses an area of the former Geamăna village (Milu et al. 2002), now almost entirely engulfed in tailings. Only a few inhabitants still live in the direct vicinity of the impoundment, the rest having been relocated. As the mine operates, the valley is systematically flooded by tailings and mine water while buildings of the former village are literally drowned in waste, from which the tower of its historical church can still be seen partially protruding (Fig. 1).

The assessment of environmental and health risks arising from the presence of such deposits of tailings as found in Valea Şesei is highly important if one considers its size and location, and is likely to require an interdisciplinary approach. Over the years, a number of unverified claims as well as anecdotal evidence regarding threats associated with this area have been raised by the media and various websites. These have included the presence of a high concentration of cyanide compounds and mercury in the wastewaters. As shown by only a few studies, waters draining freely from the ore deposit are contaminated with toxic metals (Milu et al. 2002; Melenti et al. 2011) while the entire area contributes significantly to the pollution of the river Aries and its tributaries (Levei et al. 2013). The wastes are continuously deposited as the mine operates, highlighting the necessity for monitoring of this area as regards toxicological risks.

The present study was undertaken in an effort to evaluate the chemical composition of wastewaters generated by the Rosia Poieni $\mathrm{Cu}$ mine and the associated toxicological risks. This was assessed by (i) characterizing the morphometry of the Valea Șesei tailing impoundment; (ii) a broad, multielement ICP-OES screening (total of 67 elements) and analyses of cyanide concentrations of wastewaters from this area, and (iii) toxicological studies of wastewaters by a battery of in vitro bioassays employing cells isolated from healthy human donors. The present study represents the most up to date information on the chemistry and toxicity of wastewaters from Valea Șesei and introduces biomedical tools as part of an integrated ecotoxicological assessment.

\section{Materials and methods}

\section{Study area}

The Valea Șesei is the largest Romanian tailing deposit located in the Metaliferi Mountains, a division of the Apuseni Mountains (Western Carpathians) created by flooding the dammed valley with tailings and wastewater originating from Rosia Poieni $\mathrm{Cu}$ ore, its processing, and smelting (Fig. 2). The exploitation is carried out in the open pit manner and is currently the second largest in Europe, with more than a billion tonnes of porphyry-type ore containing on average $0.36 \% \mathrm{Cu}$ (Milu et al. 2004). The dam, built from limestone blocks and gravel, is located in the northern part of the impoundment area, has a height of $118 \mathrm{~m}$, and has an inclination of $33^{\circ}$ (Duma 1998; Melenti et al. 2011). The nearest water course is the river Aries, located downhill approximately $3.5-4.0 \mathrm{~km}$ from the dam, progressing to the rivers Mures, Tisa, and finally through the river Danube into the Black Sea. Geological structures underneath the tailing deposit consist of sedimentary rocks (type not specified) on the west side and crystalline limestone on the east side. It was reported that groundwater up to $8 \mathrm{~m}$ below tailing pond are being affected by acid water seepage (Melenti et al. 2011). The surface waters can be found mainly in the southern part where the largest stream inflow is located and in the southeastern part (Fig. 2a). The area surrounding the tailing storage is hilly and covered by deciduous forests with a prevalence of beech or coniferous trees (Melenti et al. 2011). There is no fence or whatsoever to block an access to impoundment and effluent. The impoundment surroundings are still inhabited by a few locals. 


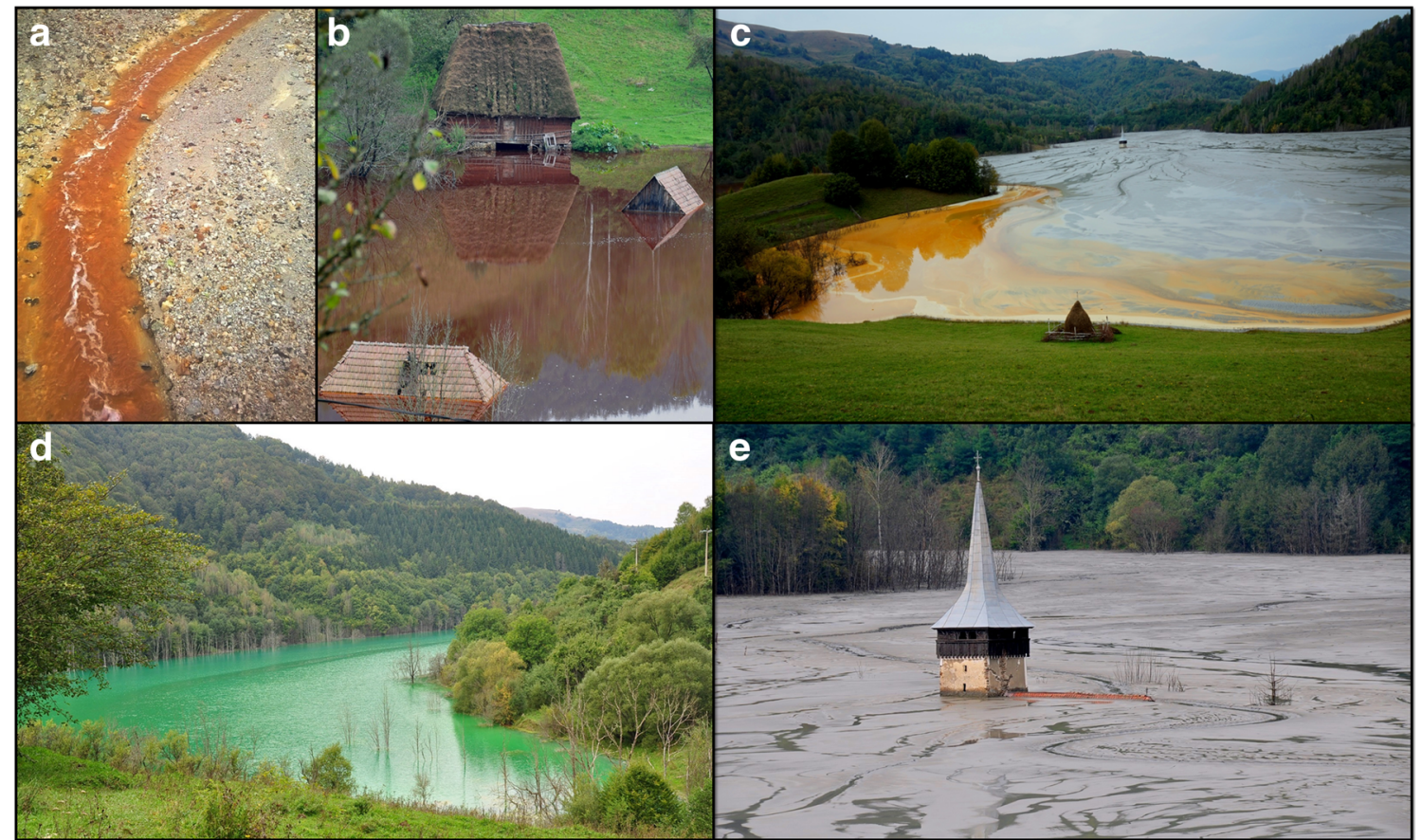

Fig. 1 Acid mine drainage inflowing from the Rosia Poieni copper mine to Valea Șesei (a) and views of different parts of tailing impoundment (b-e)

\section{Quantification of morphometry of tailing impoundment area}

An ortophotomap of Valea Șesei originating from 2012 was laid on a military topographic map scale $1: 25 \mathrm{k}$ (HTM sheets/ Hărţi topografice militare/: L-34-59-C-d; L-34-71-A-b) using ArcView software (Environmental Systems Research Institute, USA). Due to terrain generalization, the shoreline of the tailing impoundment area frequently crossed contour lines at 690 and $700 \mathrm{~m}$ a.s.l. Its course was most consistent with the outline of the $690 \mathrm{~m}$ a.s.l. contour line; thus, it was used for cartometric measurements. The topographic map was realized using a $10-\mathrm{m}$ contour interval. The bathymetric map was realized using those contours lower than $690 \mathrm{~m}$ that are precise enough to reflect isobaths of the Valea Șesei impoundment area. The total volume of impoundment was evaluated with a bathymetric map applying the formula for the truncated cone (Håkanson 1981).

\section{Sampling}

Sampling took place during summer 2016. The water samples were collected with a telescopic sampler from near the surface of the stream flowing from the area of the Rosia Poieni $\mathrm{Cu}$ mine to Valea Șesei (AMD, $46^{\circ} 19^{\prime} 04.3^{\prime \prime} \mathrm{N} 23^{\circ}$ $\left.11^{\prime} 55.7^{\prime \prime} \mathrm{E}\right)$ and from three sites WW-1 (46 $19^{\prime} 19.6^{\prime \prime} \mathrm{N} 23^{\circ}$ $\left.12^{\prime} 33.1^{\prime \prime} \mathrm{E}\right)$, WW-2 (46 $\left.16^{\prime} 31.3^{\prime \prime} \mathrm{N} 23^{\circ} 12^{\prime} 43.8^{\prime \prime} \mathrm{E}\right)$, and WW-3 (46 $\left.19^{\prime} 09.8^{\prime \prime} \mathrm{N} 23^{\circ} 13^{\prime} 22.2^{\prime \prime} \mathrm{E}\right)$ located along the shoreline of the tailing impoundment (Fig. 2). Samples were collected in 0.5 -L polypropylene bottles. Three replicates were collected for each site.

\section{Chemical analyses}

\section{General physicochemical properties}

Electrical conductivity (EC) and $\mathrm{pH}$ of collected samples were measured in situ using a portable multi-parameter probe HI9829 (Hanna Instruments, USA).

\section{Elemental composition}

The water samples were filtered through $0.45-\mu \mathrm{m}$ filters (Whatman, UK) and acidified with suprapure nitric acid (Sigma-Aldrich, Germany). Elemental analysis was performed using the inductively coupled plasma optical emission spectrometer Agilent 5100 ICP-OES (Agilent, USA). A simultaneous axial and radial view of plasma was obtained by a synchronous vertical dual view (SVDV) using dichroic spectral combiner (DSC) technology. The following common conditions were applied: radio frequency (RF) power $1.2 \mathrm{~kW}$, nebulizer gas flow $0.7 \mathrm{~L} \mathrm{~min}^{-1}$, auxiliary gas flow $1.0 \mathrm{~L} \mathrm{~min}^{-1}$, plasma gas flow $12.0 \mathrm{~L} \mathrm{~min}^{-1}$, charge-coupled device (CCD) temperature $-40{ }^{\circ} \mathrm{C}$, viewing height for radial plasma observation $8 \mathrm{~mm}$, accusation time $5 \mathrm{~s}$, three replicates. The calibration was performed using standard analytical solutions (Merck, Germany). A total of 66 elements were analyzed and grouped as follows: alkali metals $(\mathrm{Cs}, \mathrm{K}, \mathrm{Li}$, $\mathrm{Na}, \mathrm{Rb}$ ), alkaline earth metals ( $\mathrm{Ba}, \mathrm{Be}, \mathrm{Ca}, \mathrm{Mg}, \mathrm{Sr}$ ), transition 
Fig. 2 Location of studied area and sampling points (a) and morphometric characteristics of Valea Șesei tailing impoundment (b)

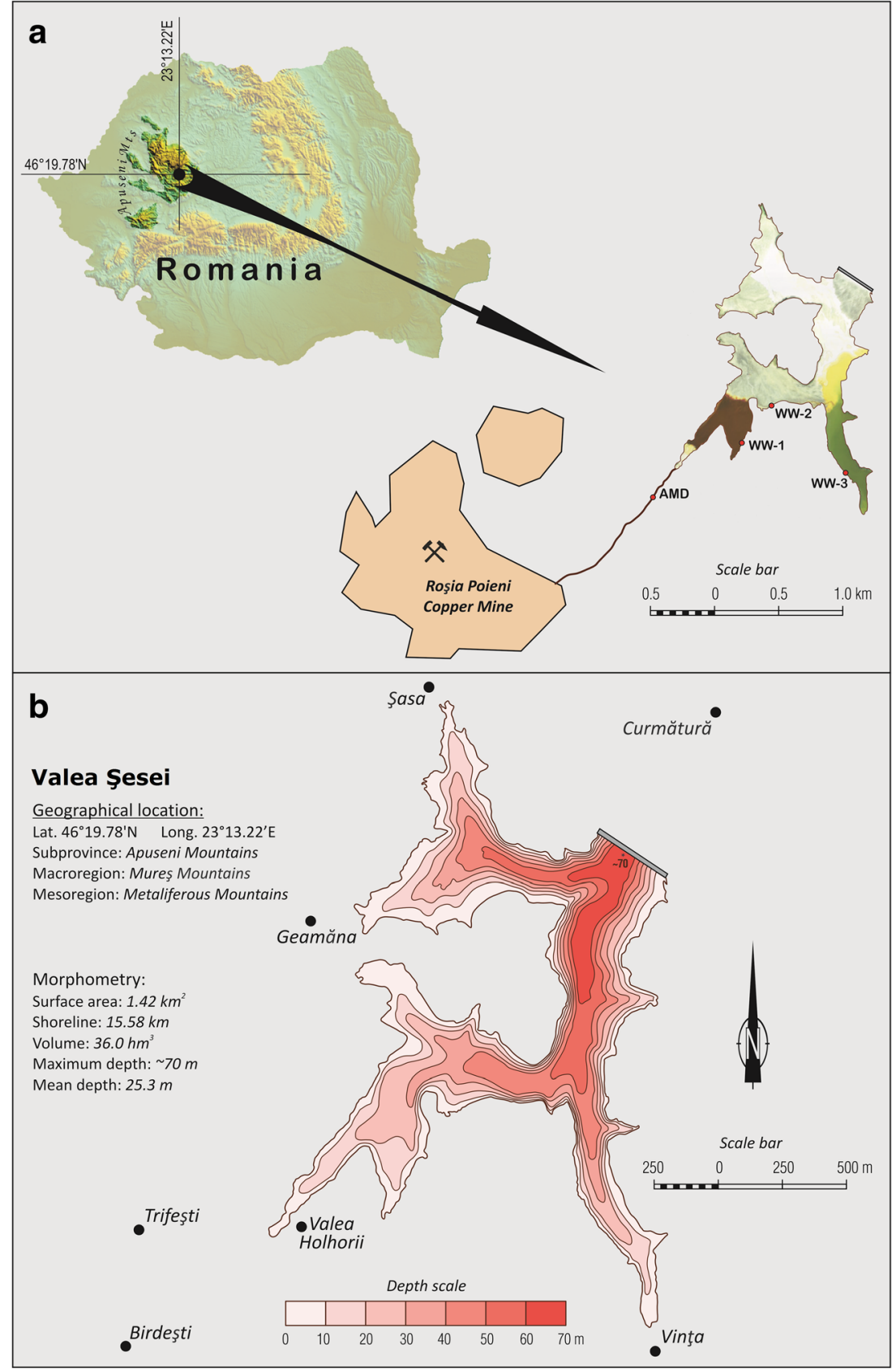

metals (Cd, Co, Cr, Cu, Fe, Hf, Hg, Mn, Mo, Nb, Ni, Ta, Ti, V, $\mathrm{W}, \mathrm{Zn}, \mathrm{Zr}$ ), post-transition metals (Al, $\mathrm{Bi}, \mathrm{Ga}$, In $\mathrm{Pb}, \mathrm{Sn}, \mathrm{Tl}$ ), metalloids (As, B, Ge, Sb, Si, Te), rare earth elements (Ce, Eu, Er, Gd, La, Nd, Pr, Sc, Sm, Dy, Ho, Lu, Tb, Tm, Y, Yb), and noble metals (Ag, Au, Ir, Os, Re, Rh, Ru, Pd, Pt). Specific information on applied wavelengths and detection limits for each element is given in the Supplementary Data (Table S1).

\section{Cyanide concentration}

After collection, water samples were preserved by adjusting their $\mathrm{pH}$ to 10 with sodium hydroxide after which they were centrifuged at $4500 \mathrm{~g}$. Total cyanide concentration was determined by a continuous flow analysis system with a photometric flow detector SAN++ (Skalar, Netherlands) according to ISO 14403-2: 2012(E). The detection limit was $5.0 \mu \mathrm{g} \mathrm{L}^{-1}$.

\section{Toxicological studies}

\section{Experimental design}

The toxicological activity of discharge waters collected from Valea Șesei was assessed and compared using a battery of in vitro assays employing human cells. Water samples were 
prepared by centrifugation at $4500 \mathrm{~g}$ and filtered through the injection filter with a nominal pore size of $0.2 \mu \mathrm{m}$ (Sartorius, Germany). The potential inducement of oxidative stress and its detrimental effects was tested in isolated neutrophils and included investigations of intracellular reactive oxygen species (ROS) generation, peroxidation of lipids, and cell survival. The potential effect on coagulation parameters, prothrombin time, and international normalized ratio was tested in separated human plasma, whereas red blood cell aggregation rate was assessed in whole blood via erythrocyte sedimentation rate. The final concentration of waters in exposed samples was always $1 \%$. For each assay, peripheral blood samples were collected from three healthy (screened by physical examination, medical history, and initial blood tests) nonsmoking and normal weighted (BMI 18.5-24.9) human donors at the Regional Centre of Blood and Blood Treatment in Poznan, Poland, according to accepted safeguard standards and legal requirements.

\section{Human neutrophils isolation}

Human neutrophils were isolated from blood samples collected in lithium heparin tubes (Becton-Dickinson, USA) using a one-step density-gradient centrifugation on Gradisol $\mathrm{G}$ of specific gravity of $1.115 \mathrm{~g} \mathrm{~mL}^{-1}$ (Polfa, Poland) at $400 \mathrm{~g}$ at room temperature for $30 \mathrm{~min}$. The residual erythrocytes were removed from the cell population by hypotonic lysis. The purity of the neutrophils ( $>90 \%$ ) was verified by counting under a light microscope after May-Grunwald-Giemsa staining.

\section{Intracellular reactive oxygen species assay}

Neutrophils were loaded for $30 \mathrm{~min}$ at $37^{\circ} \mathrm{C}$ in darkness with $20 \mu \mathrm{M}$ of $2^{\prime}, 7^{\prime}$-dichlorofluorescin diacetate (DCFDA; Abcam, UK), a fluorogenic dye that measures hydroxyl, peroxyl, and other ROS activities within the cell. Neutrophils were then washed, dissolved in PBS, and seeded in a black clear bottom 96-well plate at a density of $20 \times 10^{4}$ cells per well (99 $\mu \mathrm{L}$ aliquots/well). Water samples were added in the amount of $1 \mu \mathrm{L}$ and the plate was incubated at $37{ }^{\circ} \mathrm{C}$ for $1 \mathrm{~h}$. Fluorescence of DCFDA was measured kinetically after 5, 15, 30 , and 60 min of incubation using a Synergy HTX multi-mode plate reader (BioTek, USA) at an excitation of $495 \mathrm{~nm}$ and emission of $528 \mathrm{~nm}$. The background signal, measured in exposed neutrophils not loaded with DCFDA, was withdrawn from the corresponding samples. The final results were presented as a percentage of a parallel control constituted of neutrophils incubated with $11 \mu \mathrm{L}$ of PBS.

\section{Lipid peroxidation assay}

Lipid peroxidation was analyzed using a Lipid Peroxidation Colorimetric/Fluorometric Assay Kit (BioVision, UK) by means of malondialdehyde (MDA) content. Human neutrophils were seeded in a 96 -well plate at a density of $20 \times 10^{4}$ neutrophils per well (99 $\mu \mathrm{L}$ aliquots/well) and exposed to $1 \mu \mathrm{L}$ of each discharge water sample for $1 \mathrm{~h}$ at $37^{\circ} \mathrm{C}$. The control was constituted of cells incubated with $11 \mu \mathrm{L}$ of PBS. After the experiments, cells were harvested from each well and homogenized on ice in $300 \mu \mathrm{L}$ of provided lysis buffer (with the addition of butylated hydroxytoluene to prevent artificial lipid peroxidation) and centrifuged to remove insoluble material. The resulting $200 \mu \mathrm{L}$ of supernatants was transferred to a microcentrifuge tube and supplemented with $600 \mu \mathrm{L}$ of thiobarbituric acid (TBA) to generate an MDA-TBA adduct. To accelerate the reaction, samples were incubated at $95{ }^{\circ} \mathrm{C}$ for $60 \mathrm{~min}$ and the final product was measured colorimetrically at $532 \mathrm{~nm}$. Three technical replicates were conducted for each donor. The calculated values were compared to a calibration curve prepared using MDA standard (BioVision, UK). The coefficient of variation $\left(r^{2}\right)$ for the calibration curve was 0.99 . The final results were presented as a percentage of a parallel control.

\section{Cell viability assay}

Cell viability was determined using the colorimetric 3-(4,5dimethylthiazol-2-yl)-2,5 diphenyltetrazolium bromide (MTT) metabolic activity assay (BioVision, UK) according to the manufacturer's instructions. Human neutrophils were seeded in a 96-well plate at a density of $20 \times 10^{4}$ neutrophils per well (99 $\mu \mathrm{L}$ aliquots/well) and exposed to $1 \mu \mathrm{L}$ of each water sample for $1 \mathrm{~h}$ at $37^{\circ} \mathrm{C}$. Afterwards, cells were washed, seeded again, and $10 \mu \mathrm{L}$ of MTT was added to each well for $2 \mathrm{~h}$. Neutrophils were then treated with $10 \%$ sodium dodecyl sulfate in $0.01 \mathrm{HCl}$ and incubated for another $6 \mathrm{~h}$ in darkness to dissolve formazan crystals. The optical density (OD) of the final product (the formazan crystals) was measured at $570 \mathrm{~nm}$ using a Synergy HTX microplate reader (BioTek, USA). The final results were presented as a percentage of a parallel control constituted of neutrophils incubated with $1 \mu \mathrm{L}$ of PBS.

\section{Coagulation assay}

The effects of discharge waters on blood coagulation level were assessed with the prothrombin time measurement and calculation of the international normalized ratio (INR). Venous blood was collected in tubes containing 3.2\% sodium citrate as an anticoagulant (Sarstedt S-Monovette ${ }^{\circledR}$ 9NC). The ratio of blood to anticoagulant was no less than 10:1. Plasma was obtained by centrifugation at $1500 \times g$ at $21^{\circ} \mathrm{C}$ for $15 \mathrm{~min}$, pipetted and divided into five $990 \mu \mathrm{L}$ aliquots. The first aliquot was used as a control (with $10 \mu \mathrm{L}$ of PBS), the subsequent aliquots were exposed for $1 \mathrm{~h}$ to $10 \mu \mathrm{L}$ of each water sample at $37^{\circ} \mathrm{C}$. The prothrombin time was measured immediately with the optical nephelometric method using a K-3002 
Optic coagulometer (Kselmed, Poland) in a certified hematological laboratory. INR was calculated from the following formula:

$I N R=\frac{\text { prothrombin time for sample }}{\text { prothrombin time for laboratory reference plasma }}$

The normative laboratory range for prothrombin time and INR was 12-16 s and 0.9-1.2, respectively. Additionally, the plasma samples $(1 \mathrm{~mL})$ were exposed to a 10 -fold higher volume of samples $(100 \mu \mathrm{L})$ to magnify the potential effects; all samples were then photographed after $5 \mathrm{~min}$.

\section{Erythrocyte sedimentation rate assay}

To assess whether discharge water samples may affect the erythrocyte sedimentation rate (ESR) also known as Biernacki's reaction, $5 \mathrm{~mL}$ of venous blood of healthy donors was collected directly into BD Vacutainer Seditainer ${ }^{\mathrm{TM}}$ glass tubes containing $3.2 \%$ sodium citrate as an anticoagulant $(4: 1)$ in quintuplicate. Water samples were immediately added in the volume of $50 \mu \mathrm{L}$; tubes were inverted eight times to mix and inserted into the BD Vacutainer Seditainer ${ }^{\mathrm{TM}}$ stand for $5 \mathrm{~h}$. ESR was measured hourly and given as millimeters of sedimented red blood cells.

\section{Statistical analyses}

The results were analyzed using STATISTICA 10.0 software (StatSoft, USA). Differences in elemental composition between the investigated water samples were evaluated using one-way ANOVA with the Tukey post hoc test. In toxicological studies, the paired sample $t$ test was applied to compare the difference in effects induced by each water sample with the control. $p<0.05$ was considered as statistically significant.

\section{Results}

\section{Morphometric characteristics of tailing impoundment}

The detailed morphometry of Valea Şesei tailing impoundment is presented in Fig. 2b. The total surface area is $1.426 \mathrm{~km}^{2}$ whereas the volume of deposited tailing amounts to $36.01 \mathrm{hm}^{3}$. The depth is systematically rising in the direction of the dam with mean and maximum depth of 25.3 and $70 \mathrm{~m}$, respectively (Fig. 2b).

\section{General physicochemical properties}

All investigated water samples were characterized by low $\mathrm{pH}$ and high electrical conductivity. The determined ranges of $\mathrm{pH}$ were as follows: AMD - 2.1-2.2, WW-1-2.5-2.6, WW-2-
2.8-2.9, and WW-3-4.8-4.9; whereas mean \pm SD electrical conductivity was $15,610 \pm 80 \mu \mathrm{S} \mathrm{cm}{ }^{-1}, 7163 \pm 57 \mu \mathrm{S} \mathrm{cm}^{-1}$, $3746 \pm 62 \mu \mathrm{S} \mathrm{cm}^{-1}$, and $2800 \pm 55 \mu \mathrm{S} \mathrm{cm}^{-1}$ for AMD, WW-1, WW-2, and WW-3, respectively.

\section{Elemental composition}

Of the 65 investigated elements, the concentration of 17 of them were below the level of detection (Au, Cs, Er, Ga, Ge, Hf, Hg, Nb, Pb, Pd, Re, Ru, Sb, Sm, Sn, Ta, and Tm).

\section{Alkali metals and alkaline earth metals}

The concentration of alkali metals was diverse within the studied waters. The AMD site was characterized by the lowest $\mathrm{Na}$ and $\mathrm{K}$ concentrations which, in turn, reached the greatest level at WW-3 and exceeded 14 and $30 \mathrm{mg} \mathrm{L}^{-1}$, respectively. The highest concentration of $\mathrm{Li}$, exceeding $0.6 \mathrm{mg} \mathrm{L}^{-1}$, was found at AMD whereas Rb concentrations were similar at all studied sites and amounted on average to $3.0 \mathrm{mg} \mathrm{L}^{-1}$ (Fig. 3).

Similarly, the concentrations of alkaline earth metals were also significantly different in the investigated waters. In general, $\mathrm{Mg}$ and $\mathrm{Ca}$ were the most abundant elements of this group. The AMD site was characterized by the highest concentration of $\mathrm{Mg}$ (exceeding $550 \mathrm{mg} \mathrm{L}^{-1}$ ) and $\mathrm{Be}$ (over $0.1 \mathrm{mg} \mathrm{L}^{-1}$ ) but decidedly the lowest levels of $\mathrm{Ba}$ and $\mathrm{Ca}$. The concentration of $\mathrm{Ca}$ was at least 2-fold higher at other sites and amounted to $650 \mathrm{mg} \mathrm{L}^{-1}$ at WW-2 (Fig. 4).

\section{Selected transition and post-transition metals}

Generally, the greatest number of transition metals and their highest concentrations were identified at the AMD site (Table 1). Cr, Ti, and Zr were detected only at this site. Fe, $\mathrm{Zn}, \mathrm{Cu}$, and $\mathrm{Mn}$ were the most abundant elements of this group, with mean concentrations exceeding 4500, 600, 250, and $60 \mathrm{mg} \mathrm{L}^{-1}$, respectively. The AMD site was also characterized by increased levels of Co (over $2.0 \mathrm{mg} \mathrm{L}^{-1}$ ), Cd, and $\mathrm{Ni}$ (over $1.0 \mathrm{mg} \mathrm{L}^{-1}$ each) and a relatively high concentration of $\mathrm{V}$ and $\mathrm{W}$ (over $0.5 \mathrm{mg} \mathrm{L}^{-1}$ each). The decidedly lowest concentration of transition metals was found at WW-2, with a number of elements below the limit of detection and trace quantities of $\mathrm{Fe}$ and $\mathrm{Zn}$ (Table 1.)

Al was the most abundant element from the group of post-transition metals. Its high concentrations were identified for each site except WW-2 (Table 1). At AMD, its mean level exceeded $4400 \mathrm{mg} \mathrm{L}^{-1}$. The concentrations of other elements of this group were relatively low. The highest concentrations of $\mathrm{Bi}$ and $\mathrm{In}\left(>0.5 \mathrm{mg} \mathrm{L}^{-1}\right)$ were found at the AMD site (Table 1). 
Fig. 3 A-D The concentrations of selected alkali metals in water samples collected at Valea Șesei. Identical superscripts $(a, b, c)$ denote no significant $(p>0.05)$ difference between mean values in rows according to Tukey's HSD test (ANOVA). $D L$ detection limit. Cs was not detected in any sample
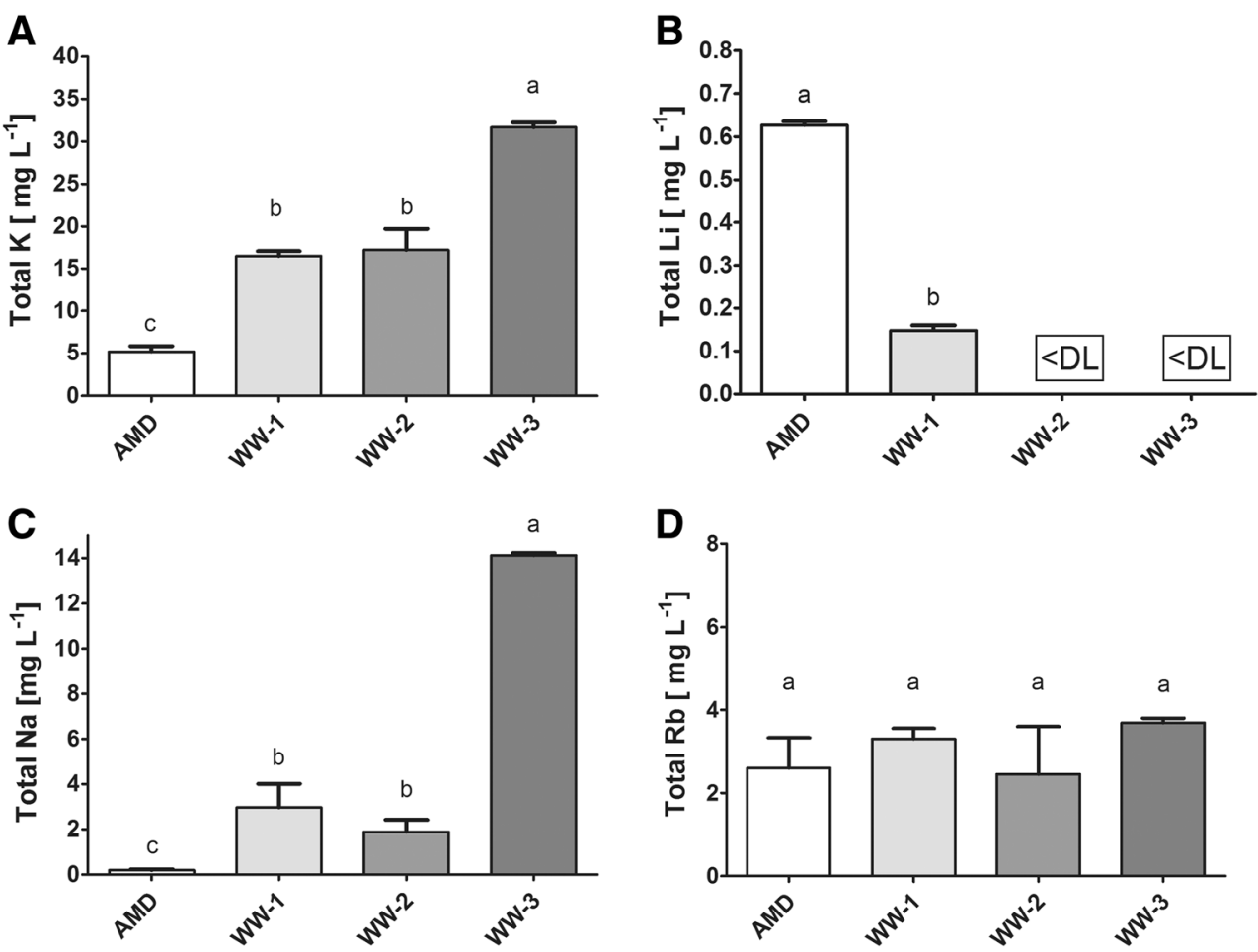

\section{Metalloids}

The highest concentration of detected metalloids was again found at the AMD site. As and Te were identified above the limit of detection only for this site. Compared to WW-1, WW2, and WW-3, Si concentrations at AMD were 3-fold, 66-fold, and 18-fold higher, respectively (Table 2).

\section{Rare earth elements}

The investigated waters contained high concentrations of REEs. The total concentration of identified elements ranged from 0.137 (WW-3) to 7.41 (AMD) $\mathrm{mg} \mathrm{L}^{-1}$. The greatest number of light REEs (Ce, Eu, Gd, La, Nd, Pr, Sc) and heavy REEs (Dy, Ho, Lu, Tb, Y, and $\mathrm{Yb}$ ) and their highest concentrations were noted for AMD. The general mean concentration of elements at AMD decreased in the following order: $\mathrm{Y}>\mathrm{Sc}>\mathrm{Nd}>\mathrm{Gd}>\mathrm{Dy}>\mathrm{Ce}>\mathrm{Pr}>\mathrm{Yb}>\mathrm{Ho}>\mathrm{La}>\mathrm{Lu}>\mathrm{Eu}>\mathrm{Tb}$. In particular, the concentration of $\mathrm{Y}$ at this site was exceptionally high and exceeded $2 \mathrm{mg} \mathrm{L}^{-1}$ (Table 3 ).

\section{Noble elements}

The greatest concentration of noble elements was identified at AMD. Levels of Pt for this sample exceeded $40 \mathrm{mg} \mathrm{L}^{-1}$ on average. Relatively high concentrations of Os (over $8 \mathrm{mg} \mathrm{L}^{-1}$ ) and Ir (over $1 \mathrm{mg} \mathrm{L}^{-1}$ ) were also observed. The lowest concentrations of noble metals were detected at WW-2 and WW-3 with Ir and Pt falling below the detection limit (Table 4).

\section{Cyanide concentration}

Total concentration of cyanides was below the limit of detection $\left(5 \mu \mathrm{g} \mathrm{L}^{-1}\right)$ in all investigated samples.

\section{In vitro toxicity}

Assays employing human neutrophils revealed that exposure to all samples resulted in elevated production of ROS with rapid onset of action. The greatest increase, observed over the entire exposure time, was triggered by AMD and WW-1. Compared to the control, the ROS content after $1 \mathrm{~h}$ of exposure was higher by 41.1 and $25.0 \%$, respectively (Fig. 5a). Both samples caused significant lipid peroxidation, as measured by MDA concentrations, elevated by $86.6 \%$ for AMD and $18.5 \%$ for WW-1 by the end of the experiment (Fig. 5b). This was also followed by greatly decreased cell viability, particularly in the case of AMD. For this sample, neutrophil survival was only of $36.6 \%$ of the control level (Fig. 5c).

The addition of $50 \mu \mathrm{L}$ of the investigated waters to $5 \mathrm{~mL}$ of human whole blood samples resulted in significantly increased ESR only under the influence of AMD. This effect was observed after regular $60 \mathrm{~min}$ of assay (with $5 \mathrm{~mm}$ of mean difference with the control) and remained visible for the next $4 \mathrm{~h}$ of incubation. Mean difference in ESR between AMD and the control over the entire experiment was $10.7 \mathrm{~mm}$ (Fig. 5d).

Exposure of human plasma to AMD, WW-1, and WW-3 caused prolonged clotting as evidenced by elevated prothrombin time and INR values. In all cases, levels of both INR 

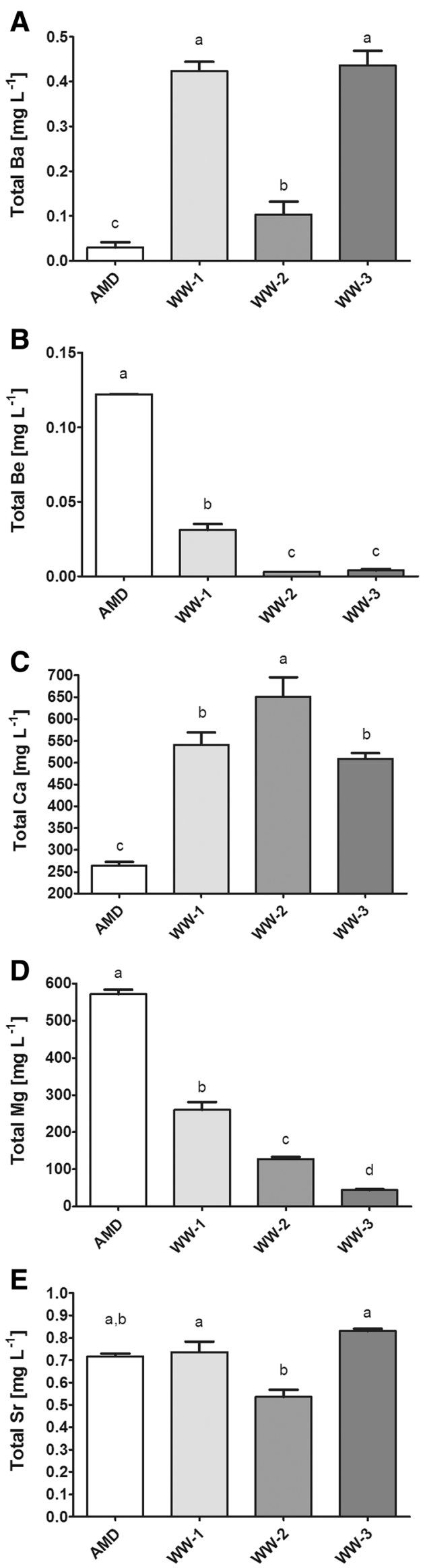

4 Fig. 4 A-E The concentrations of selected alkaline earth metals in water samples collected at Valea Șesei. Identical superscripts $(a, b, c)$ denote no significant $(p>0.05)$ difference between mean values in rows according to Tukey's HSD test (ANOVA)

exceeded the laboratory normative value. The most significant coagulopathic effects were exhibited by AMD - the INR values and prothrombin time amounted to 149.5 and $142.6 \%$ of the control level, respectively (Fig. 5e). When the plasma was exposed to a 10-fold higher concentration of each sample $(100 \mu \mathrm{L})$, formation of white slime could be observed for the AMD-exposed sample in a time as short as $5 \mathrm{~min}$. No visible effects were recorded for other samples (Fig. 5f).

All in all, the tested discharge waters, particularly AMD and WW-1, revealed significant toxicity in human cells causing substantial adverse reactions with short onset time such as inducement of oxidative stress and decreased cell viability in human neutrophils, increased blood plasma prothrombin time and erythrocyte sedimentation rate. The general toxicity of the investigated water decreased in the following order: AMD $>$ WW-1 > WW-3 > WW-2.

\section{Discussion}

The present work is one of the broadest investigations of the multi-element content in wastewaters generated from $\mathrm{Cu}$ mining activities. It may thus represent a reference point for observed concentrations in future studies conducted at Valea Şesei or other areas of mining waste discharge.

Although the wastewaters in Valea Șesei were found to possess an extremely enriched chemical matrix as indicated by elemental concentrations and high electrical conductivity, no cyanides were detected. Cyanides, along with $\mathrm{Hg}$ compounds, were reported to allegedly occur at high concentrations in Valea Şesei by some media and websites, although cyanides are not employed in $\mathrm{Cu}$ ore processing. Instead, separation of Au may employ a very dilute sodium cyanide solution, a method considered to be a much safer alternative to gold extraction by liquid mercury, previously used on the large scale (Adams 2016). In fact, Hg levels were also below the limit of detection in all the samples investigated in the present study. This not only highlights that cyanides and $\mathrm{Hg}$ compounds are unlikely to be a subject of concern in Valea Șesei but also that claims of their presence are rather the result of confusing the $\mathrm{Cu}$ activities of Rosia Poieni with the historical use of the nearby gold mine Rosia Montanta, now no longer in operation (Stefãnescu et al. 2013).

Surprisingly, the investigated wastewaters were characterized by no detectable level of $\mathrm{Pb}$ and relatively low levels of As identified only at the AMD site. Both elements are commonly found in mine waters, including acid mine drainage (Stumbea 2013; Migaszewski et al. 2016). However, at very 
Table 1 Mean $\pm \mathrm{SD}$ (maximum) content $\left(\mathrm{mg} \mathrm{L}^{-1}\right)$ of transition and post-transition metals in water samples $(n=3)$ collected at Valea Sesei

\begin{tabular}{|c|c|c|c|c|}
\hline & AMD & WW-1 & WW-2 & WW-3 \\
\hline \multicolumn{5}{|c|}{ Transition metals } \\
\hline $\mathrm{Cd}$ & $1.08 \pm 0.18^{\mathrm{a}}(1.20)$ & $0.22 \pm 0.01^{\mathrm{b}}(0.24)$ & $<\mathrm{DL}$ & $0.01 \pm 0.002^{\mathrm{c}}(0.0167)$ \\
\hline $\mathrm{Co}$ & $2.20 \pm 0.35^{\mathrm{a}}(2.47)$ & $0.88 \pm 0.07^{\mathrm{b}}(0.96)$ & $<\mathrm{DL}$ & $0.003 \pm 0.006^{\mathrm{C}}(0.004)$ \\
\hline $\mathrm{Cr}$ & $0.02 \pm 0.02(0.04)$ & $<\mathrm{DL}$ & $<\mathrm{DL}$ & $<\mathrm{DL}$ \\
\hline $\mathrm{Cu}$ & $259.3 \pm 52.4^{\mathrm{a}}(291.1)$ & $86.4 \pm 6.4^{\mathrm{b}}(93.0)$ & $<\mathrm{DL}$ & $2.77 \pm 0.22^{\mathrm{c}}(2.95)$ \\
\hline $\mathrm{Fe}$ & $4669.6 \pm 727.9^{\mathrm{a}}(5118.2)$ & $410.9 \pm 46.7^{\mathrm{b}}(459.1)$ & $0.23 \pm 0.41^{\mathrm{c}}(0.71)$ & $0.006 \pm 0.01^{\mathrm{c}}(0.01)$ \\
\hline Mn & $62.3 \pm 11.4^{\mathrm{a}}(69.8)$ & $25.2 \pm 1.8^{\mathrm{b}}(26.9)$ & $2.45 \pm 0.74^{\mathrm{c}}(3.28)$ & $3.82 \pm 0.31^{\mathrm{c}}(4.09)$ \\
\hline Mo & $0.01 \pm 0.007^{\mathrm{a}}(0.015)$ & $0.002 \pm 0.003^{\mathrm{a}}(0.006)$ & $0.005 \pm 0.005^{\mathrm{a}}(0.01)$ & $0.02 \pm 0.003^{\mathrm{a}}(0.025)$ \\
\hline $\mathrm{Ni}$ & $\begin{array}{l}1.48 \pm 0.26^{\mathrm{a}} \\
(1.65)\end{array}$ & $0.36 \pm 0.03^{\mathrm{b}}(0.39)$ & $<\mathrm{DL}$ & $0.03 \pm 0.007^{\mathrm{c}}(0.035)$ \\
\hline $\mathrm{Ti}$ & $0.03 \pm 0.03(0.200)$ & $<\mathrm{DL}$ & $<\mathrm{DL}$ & $<\mathrm{DL}$ \\
\hline $\mathrm{V}$ & $0.508 \pm 0.165^{\mathrm{a}}(0.606)$ & $<\mathrm{DL}$ & $0.001 \pm 0.001^{\mathrm{b}}(0.003)$ & $<\mathrm{DL}$ \\
\hline W & $0.711 \pm 0.228(0.902)$ & $<\mathrm{DL}$ & $<\mathrm{DL}$ & $<\mathrm{DL}$ \\
\hline $\mathrm{Zn}$ & $610.9 \pm 129.9^{\mathrm{a}}(692.7)$ & $65.6 \pm 7.8^{\mathrm{b}}(74.2)$ & $0.04 \pm 0.02^{\mathrm{d}}(0.06)$ & $4.89 \pm 0.35^{\mathrm{c}}(5.14)$ \\
\hline $\mathrm{Zr}$ & $0.03 \pm 0.03(0.06)$ & $<\mathrm{DL}$ & $<\mathrm{DL}$ & $<\mathrm{DL}$ \\
\hline \multicolumn{5}{|c|}{ Post-transition metals } \\
\hline $\mathrm{Al}$ & $4488.3 \pm 831.1^{\mathrm{a}}(5014.8)$ & $826.1 \pm 68.1^{\mathrm{b}}(894.4)$ & $0.19 \pm 0.17^{\mathrm{d}}(0.34)$ & $8.94 \pm 0.14^{\mathrm{c}}(9.10)$ \\
\hline $\mathrm{Bi}$ & $0.61 \pm 0.10^{\mathrm{a}}(0.71)$ & $0.07 \pm 0.08^{\mathrm{b}}(0.18)$ & $0.14 \pm 0.03^{\mathrm{b}}(0.17)$ & $0.07 \pm 0.03^{\mathrm{b}}(0.10)$ \\
\hline In & $0.50 \pm 0.11^{\mathrm{a}}(0.62)$ & $0.26 \pm 0.05^{\mathrm{b}}(0.32)$ & $0.35 \pm 0.04^{\mathrm{ab}}(0.40)$ & $0.34 \pm 0.05^{\mathrm{ab}}(0.39)$ \\
\hline $\mathrm{Tl}$ & $0.09 \pm 0.09^{\mathrm{a}}(0.20)$ & $<\mathrm{DL}$ & $0.01 \pm 0.02^{\mathrm{a}}(0.04)$ & $0.03 \pm 0.06^{\mathrm{a}}(0.11)$ \\
\hline
\end{tabular}

$\mathrm{Au}, \mathrm{Ga}, \mathrm{Hf}, \mathrm{Hg}, \mathrm{Nb}, \mathrm{Pd}, \mathrm{Re}, \mathrm{Sn}$, and Ta were not identified in any sample. Identical superscripts (a, b, c, d) denote no significant $(p>0.05)$ difference between mean values in rows according to Tukey's HSD test (ANOVA)

$D L$ detection limit

low $\mathrm{pH}$, adsorption of $\mathrm{As}$ and $\mathrm{Pb}$ on the surface of particles is very efficient and may reduce the concentrations observed in the inflowing water (Zhang 2011). Large quantities of As can also be removed by co-precipitation with $\mathrm{Fe}(\mathrm{III})$, the process found to result from microbial As and Fe oxidation (Casiot et al. 2003). Nevertheless, tailings originating from $\mathrm{Cu}$ extraction can contain high levels of these elements. As demonstrated by Levei et al. 2013, the tailings deposited in Valea Şesei contained over $30 \mathrm{mg} \mathrm{kg}^{-1}$ of $\mathrm{Pb}$ and $8 \mathrm{mg} \mathrm{kg}^{-1}$ of As but their leachability was low. Immobilization reduces direct environmental risks arising from $\mathrm{As}$ and $\mathrm{Pb}$ contamination but the problem persists if one considers the total volume, size, and setting of the valley deposits located at Valea Șesei.
The mean contents of detected elements in the investigated samples generally decreased in the following order: $\mathrm{Fe}>\mathrm{Al}>\mathrm{Ca}>\mathrm{Mg}>\mathrm{Zn}>\mathrm{Cu}>\mathrm{Si}>\mathrm{Mn}>\mathrm{Pt}>\mathrm{K}>\mathrm{Na}>\mathrm{Rb}>\mathrm{Os}>$ $\mathrm{Ir}>\mathrm{B}>\mathrm{Y}>\mathrm{Co}>\mathrm{Gd}>\mathrm{W}>\mathrm{Sr}>\mathrm{Ni}>\mathrm{Te}>\mathrm{Sc}>\mathrm{Cd}>\mathrm{Dy}>\mathrm{In}>\mathrm{Li}>$ $\mathrm{Ce}>\mathrm{Nd}>\mathrm{V}>\mathrm{Ba}>\mathrm{Bi}>\mathrm{Pr}>\mathrm{As}>\mathrm{Ho}>\mathrm{Yb}>\mathrm{La}>\mathrm{Lu}>\mathrm{Tl}>\mathrm{Ag}>\mathrm{Zr}>\mathrm{Ti}>-$ $\mathrm{Cr}>\mathrm{Eu}>\mathrm{Be}>\mathrm{Rh}>$ Mo. Based on the identified contents (particularly for acid mine drainage; AMD site), six main groups of elements could be classified: (i) those that can exceed $1000 \mathrm{mg} \mathrm{L}^{-1}$ ( $\mathrm{Fe}$ and $\mathrm{Al}$ ); (ii) ranging from 100 to $1000 \mathrm{mg} \mathrm{L}^{-1}$ (Ca, $\mathrm{Mg}, \mathrm{Zn}$, and $\mathrm{Cu}$ ); (iii) ranging from 10 to $100 \mathrm{mg} \mathrm{L}^{-1}$ (Si, Mn, Pt, and $\mathrm{K}$ ); (iv) ranging from 1 to $10 \mathrm{mg} \mathrm{kg} \mathrm{L}^{-1}$ (Na, Rb, Os, Ir, B, Y, and Co); (v) ranging from 0.1 to $1 \mathrm{mg} \mathrm{kg} \mathrm{L}^{-1}$ (Gd, W, Sr, Ni, Te, Sc, Cd, Dy, In, Li, Ce,
Table 2 Mean $\pm \mathrm{SD}$ (maximum) content $\left(\mathrm{mg} \mathrm{L}^{-1}\right)$ of metalloids in water samples $(n=3)$ collected at Valea Sesei

\begin{tabular}{|c|c|c|c|c|}
\hline & AMD & WW-1 & WW-2 & WW-3 \\
\hline As & $0.107 \pm 0.05(0.153)$ & $<\mathrm{DL}$ & $<\mathrm{DL}$ & $<\mathrm{DL}$ \\
\hline B & $6.63 \pm 1.38^{\mathrm{a}}(7.50)$ & $0.54 \pm 0.07^{\mathrm{b}}(0.63)$ & $0.05 \pm 0.07^{\mathrm{b}}(0.06)$ & $0.03 \pm 0.02^{\mathrm{b}}(0.04)$ \\
\hline $\mathrm{Si}$ & $85.7 \pm 14.9^{\mathrm{a}}(95.2)$ & $28.1 \pm 2.1^{\mathrm{b}}(30.2)$ & $1.30 \pm 0.07^{\mathrm{c}}(1.36)$ & $4.70 \pm 0.4^{\mathrm{c}}(5.0)$ \\
\hline $\mathrm{Te}$ & $0.51 \pm 0.25(0.75)$ & $<\mathrm{DL}$ & $<\mathrm{DL}$ & $<\mathrm{DL}$ \\
\hline
\end{tabular}

$\mathrm{Ge}$ and $\mathrm{Sb}$ were not identified in any sample. Identical superscripts $(\mathrm{a}, \mathrm{b}, \mathrm{c})$ denote no significant $(p>0.05)$ difference between mean values in rows according to Tukey's HSD test (ANOVA)

$<D L$ below detection limit 


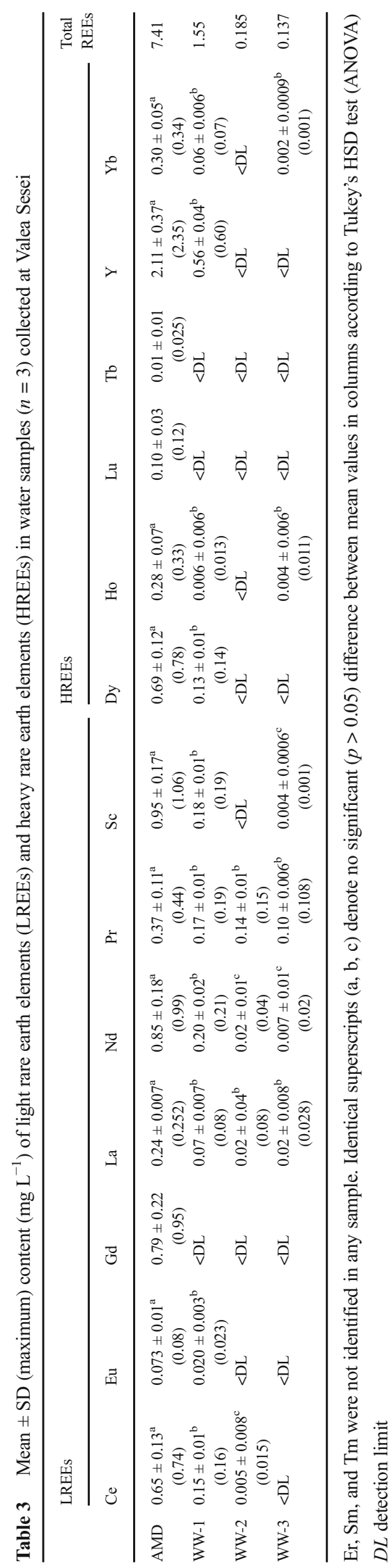

$\mathrm{Nd}, \mathrm{V}, \mathrm{Ba}, \mathrm{Bi}, \mathrm{Pr}, \mathrm{As}, \mathrm{Ho}, \mathrm{Yb}, \mathrm{La}$, and $\mathrm{Lu}$ ); and (vi) below $0.1 \mathrm{mg} \mathrm{L}^{-1}$ (Tl, Ag, Zr, Ti, Cr, Eu, Be, Rh, Tb, and Mo). Their contents were relatively homogeneous as reflected by generally low values of SD calculated for each element. Generally, the concentrations of majority of studied elements largely exceeded those observed in surface waters, including environments under high human pressure (Rzymski et al. 2014; Jitar et al. 2015; Strungaru et al. 2015; Antonowicz et al. 2016; Plavan et al. 2017).

The greatest element concentrations were most decidedly present at the AMD site where mine waters of low $\mathrm{pH}$ flow downhill. It is known that acid mine drainage can mobilize and transport large quantities of different elements including toxic metals, metalloids, and REEs (Migaszewski et al. 2014; Migaszewski et al. 2016). In the case of the studied area, waters flowing from the AMD site reach the tailing impoundment and enrich the deposited waste. As shown, the concentration of elements decreased in the order AMD $>$ WW-1 > WW-2 indicating the systematic immobilization of inflowing chemicals. The transfer of dissolved elements from the aqueous phase to the particle phase is due to sorption processes whose efficiency increases with pH (Karlsson et al. 1987). However, it has been demonstrated that various elements are preferably adsorbed within the uppermost layer of the tailings (Müller et al. 2002) and that under certain circumstances, metals and metalloids can be re-released, mostly if extensively oxidized (Moncur et al. 2005). At the WW-3 site, the concentrations were higher than at WW-2 indicating that these waters are probably enriched from other sources (e.g., smaller inflows from the mine area). All in all, the Valea Şesei functions as a large sink for chemical elements (including economically important ones, e.g., $\mathrm{Ag}, \mathrm{Pt}$, and other noble metals) inflowing from the mine area and the ore processing plant. There is no doubt that this area must affect the surrounding environment, including the quality of surface and groundwaters, as already evidenced by Milu et al. 2002.

The present study also demonstrated a battery of in vitro bioassays to directly assess the toxicity of collected wastewaters instead of predicting it from elemental concentrations and other physico-chemical parameters. All of these tests employed human blood or isolated human cells, thereby including individual variability and susceptibility. The exposure times were, in turn, short in contrast to those employing cell lines that usually require culturing and a longer assay time to allow for cell responses. For these reasons, the observed effects may be even more relevant for human risk assessment. Despite this, the methods applied in the present work are rarely used to evaluate toxicity of water samples (Zegura et al. 2009), although the employed assays are commonly used in biomedical, pharmacological, and toxicological sciences, including studies on adverse effects of aquatic toxins, e.g., cyanobacterial metabolites (Pizon et al. 2011; Poniedziałek 
Table 4 Mean $\pm \mathrm{SD}$ (maximum) content $\left(\mathrm{mg} \mathrm{L}^{-1}\right)$ of noble metals $(\mathrm{NM})$ in water samples $(n=3)$ collected from area of Valea Sesei in Romania

NMs

Total NMs

\begin{tabular}{lllllll} 
& Ag & Ir & Os & Rh & Pt & \\
\hline AMD & $0.09 \pm 0.05^{\mathrm{a}}(0.153)$ & $1.93 \pm 0.41(2.28)$ & $8.12 \pm 1.65^{\mathrm{a}}(9.20)$ & $0.048 \pm 0.040^{\mathrm{a}}(0.081)$ & $43.01 \pm 9.23^{\mathrm{a}}(48.7)$ & 53.2 \\
WW-1 & $0.05 \pm 0.03^{\mathrm{a}}(0.057)$ & $<\mathrm{DL}$ & $0.62 \pm 0.06^{\mathrm{b}}(0.70)$ & $0.01 \pm 0.01^{\mathrm{a}}(0.03)$ & $2.65 \pm 0.31^{\mathrm{b}}(2.98)$ & 3.3 \\
WW-2 & $0.04 \pm 0.02^{\mathrm{a}}(0.050)$ & $<\mathrm{DL}$ & $0.14 \pm 0.01^{\mathrm{b}}(0.16)$ & $0.01 \pm 0.01^{\mathrm{a}}(0.025)$ & $<\mathrm{DL}$ & 0.19 \\
WW-3 & $0.04 \pm 0.01^{\mathrm{a}}(0.049)$ & $<\mathrm{DL}$ & $0.13 \pm 0.01^{\mathrm{b}}(0.14)$ & $0.005 \pm 0.007^{\mathrm{a}}(0.0135)$ & $<\mathrm{DL}$ & 0.17 \\
\hline
\end{tabular}

$\mathrm{Au}, \mathrm{Pd}$, and $\mathrm{Ru}$ were not identified in any sample. Identical superscripts $(\mathrm{a}, \mathrm{b})$ denote no significant $(p>0.05)$ difference between mean values in rows according to Tukey's HSD test (ANOVA)

$D L$ detection limit

et al. 2014; Poniedziałek et al. 2015b; Al Musawi et al. 2016; Rzymski et al. 2017).

The first set of assays utilized isolated human neutrophils, the most abundant leukocytes, facilitating the innate immune response (Nathan 2006). As previously shown, these cells represent a convenient and rapid in vitro model to test cytotoxicity and elucidate its mechanism of action
(Poniedziałek et al. 2015a; Rzymski et al. 2015, 2017). Monitoring of intracellular ROS evaluated whether any of tested wastewaters can induce oxidative stress, an imbalance between ROS generation and biological system ability to readily detoxify the reactive intermediates or to repair the resulting damage (Halliwell and Gutteridge 2007). The potential detrimental outcomes of this phenomenon include a
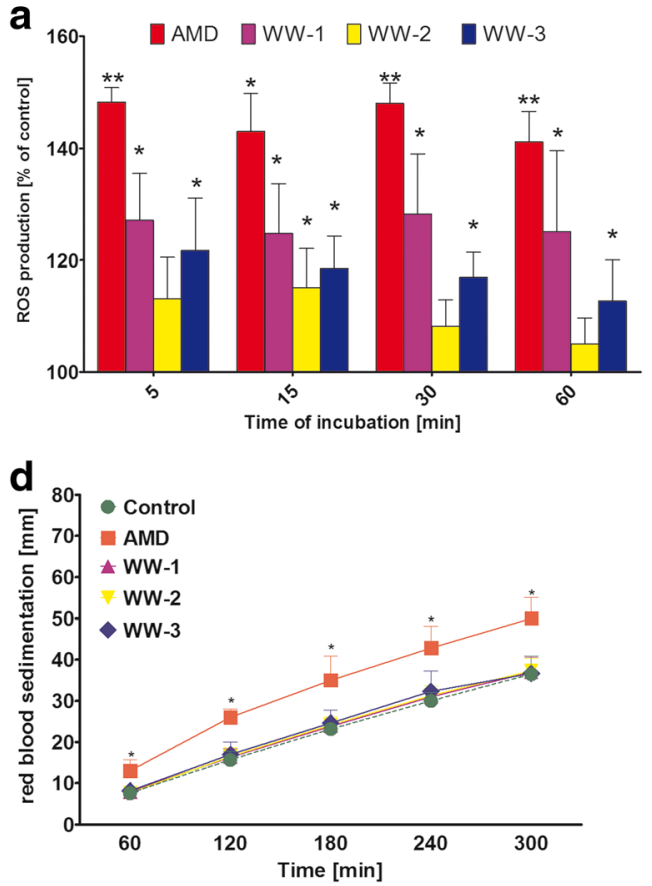

Fig. 5 a The intracellular ROS concentrations in human neutrophils exposed for $1 \mathrm{~h}$ to water samples collected at Valea Șesei measured by means of DCFDA fluorescence and expressed as percentage of control. Bars represent mean \pm SD from three independent experiments corresponding to different donors. Asterisks represent statistically significant difference to the control $(* p<0.05 ; * * p<0.01$; paired sample $t$ test). b The viability of human neutrophils exposed for $1 \mathrm{~h}$ to water samples collected at Valea Șesei measured by means of mitochondrial activity in MTT assay and expressed as percentage of control. Bars represent mean \pm SD from five independent experiments corresponding to different donors. Asterisks represent statistically significant difference to the control $\left({ }^{*} p<0.05\right.$; $* * p<0.01$; paired

\section{c}

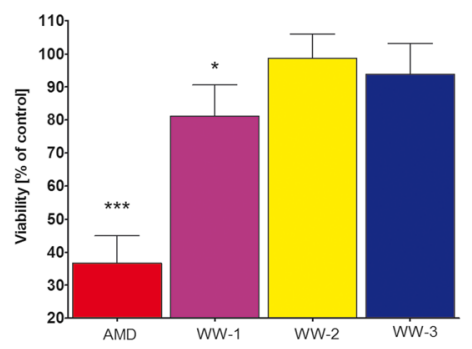

f

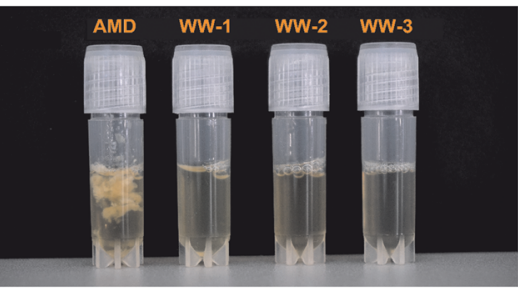

sample $t$ test). c The erythrocyte sedimentation rate measured for human whole blood exposed for $5 \mathrm{~h}$ to water samples collected at Valea Şesei. Bars represent mean \pm SD from three independent experiments corresponding to different donors. Values recorded for the AMD sample at each interval were significantly different from the corresponding control $(* p<0.05$; paired sample $t$ test). (d) Coagulation parameters measured in human plasma for $1 \mathrm{~h}$ to water samples collected at Valea Şesei. Asterisks represent statistically significant difference to the control $(* p<0.05 ; * * p<0.01$; paired sample $t$ test). e Photograph of human plasma $(1 \mathrm{~mL})$ exposed for $5 \mathrm{~min}$ to water samples $(100 \mu \mathrm{L})$ collected at Valea Sesei. Note white suspension visible in plasma exposed to AMD 
DNA damage, protein modifications, lipid peroxidation, and necrotic or apoptotic cell death (Halliwell and Gutteridge 2007; Poniedziałek et al. 2015b; Komosa et al. 2017). In the present study, the two latter effects were also assessed to determine whether any potential change in ROS levels produced adverse effects or whether neutrophils had the ability to cope with them through adaptive responses.

As found, all wastewaters caused an immediate redox imbalance through significant increase in neutrophil ROS levels, particularly high in the presence of AMD and WW-1 samples. This resulted in an increased peroxidation of lipids, a chain reaction initiated by the hydrogen abstraction or addition of an oxygen radical, resulting in the oxidative damage of polyunsaturated fatty acids. If not terminated fast enough, a decrease in membrane fluidity and in the barrier functions of membranes is induced, final products of peroxidation (predominantly MDA and 4-hydroxy-2-nonenal) can induce genotoxicity, and cell death is promoted (Burcham 1998; Ayala et al. 2014). AMD and WW-1 waters reduced cell survival with the viability of neutrophils decreasing by over $60 \%$ and nearly $20 \%$, respectively.

While neutrophil-based assays elucidated the mechanism of toxic action of the investigated samples, the present study also aimed to evaluate more general toxic effects. Blood coagulation is an important feature of the vascular system that involves activation, adhesion, and aggregation of platelets along with deposition and maturation of fibrin (Lillicrap et al. 2009), and different chemical compounds are known to interfere with it (Pizon et al. 2011). As demonstrated, all tested samples except WW-2 elevated prothrombin time and INR values above the laboratory normative ranges - the greatest increase was again found for AMD. This implies that exposure of plasma resulted in inhibition of coagulation factors involved in extrinsic and common pathways that triggered impaired fibrinogen clottability (Palta et al. 2014). Increased blood clotting has been shown to play a role in the toxicity exhibited by compounds of various elements, including iron (Rosenmund et al. 1984), Cu (AbouShady et al. 1991a), and zinc (Abou-Shady et al. 1991b). In turn, other elements such as cadmium or aluminum are known to cause hypercoagulation (Koçak and Akçil 2006). Therefore, the coagulopathy observed in the present study is most likely to be the result of the simultaneous interaction of many different elements with key players in coagulation pathways - platelets, microparticles, and the clotting factors. It should be stressed that although the differences in prothrombin time and INR values were significant in the present study, the observed effects were not as pronounced as for some chemical compounds, e.g., detergent sclerosants (Parsi et al. 2007).

The last assay employed in the present study was ESR which is routinely used as a non-specific marker of inflammation (Brigden 1998). It is an inexpensive, simple laboratory test conducted on the whole blood (thus in the presence of autologous cellular and serum components that may be physiologically relevant) and allows the results to be easily observable and measured. The ESR depends on the aggregation rate of red blood cells, the phenomenon affected by the size, shape, and number of the red cells, and plasma fibrinogen and globulin levels (Fabry 1987). The present study observed significantly increased ESR only in human blood exposed to AMD. The plausible cause of this includes the destruction of erythrocytes, the subsequent decrease in their count, and eventual increase in sedimentation rate. The association between low hematocrit and high ESR is observed for example in anemia due to altered velocity of the upward flow of plasma resulting in a faster fall of red blood cell aggregates (Brigden 1999). High ESR may also (or additionally) result from a partial loss of albumin (Fabry 1987). Nevertheless, the present study demonstrated that ESR can be a convenient in vitro tool to monitor humanrelated toxicities for industrially discharged waters.

The magnitude of the observed toxic effects did not directly follow the trends in $\mathrm{pH}$ or electrical conductivity of the investigated water samples; it appeared to be associated with their concentrations of elements, particularly toxic metals. The greatest alterations of neutrophil redox balance and cell survival, plasma clotting, and aggregation of red blood cells were induced by AMD, rich in $\mathrm{Al}, \mathrm{Fe}, \mathrm{Cd}$, As, and REEs. It is most likely that their toxicity was increased due to very low $\mathrm{pH}$. Under such conditions, the bioavailability of various elements is generally increased, e.g., $\mathrm{Al}$ occurs as toxic $\mathrm{Al}^{3}+$ ion (Krewski et al. 2007). The least adverse effects were revealed by WW-2, still very acidic $(\mathrm{pH}<3)$ but generally characterized by the lowest concentrations of elements with evidenced toxicity. The present study demonstrates that the bioassays applied in our study can be an integral part of toxicological evaluation, monitoring, and risk assessment of wastewaters from mining activities.

\section{Conclusions}

The present study demonstrates that wastewaters deposited along with tailings in Valea Șesei in the Apuseni Mountains, Romania, represent a serious environmental and health risk if released on the larger scale. Considering that the mine still operates and generates continuous disposal, there is a strict necessity to prevent any possibility of dam failure and to initiate restoration management in the studied area.

Acknowledgements Piotr Rzymski is supported by the Foundation for Polish Science (FNP) (START 091.2016).

Open Access This article is distributed under the terms of the Creative Commons Attribution 4.0 International License (http:// 
creativecommons.org/licenses/by/4.0/), which permits unrestricted use, distribution, and reproduction in any medium, provided you give appropriate credit to the original author(s) and the source, provide a link to the Creative Commons license, and indicate if changes were made.

\section{References}

Abou-Shady EA, Farrag HE, el-Damarawy NA, Mohammed FA, Kamel AM, Massoud AA (1991a) In vitro effects of trace elements on blood clotting and platelet function. B-zinc and magnesium. J Egypt Public Health Assoc 66:49-72

Abou-Shady EA, Farrag HE, el-Damarawy NA, Mohamed FA, Kamel AM, Massoud AA (1991b) In vitro effects of trace elements on blood clotting and platelet function. A-iron, copper, and gold. J Egypt Public Health Assoc 66:21-48

Adams M (2016) Gold ore processing (second edition) project development and operations. Elsevier Science, Amsterdam

Akcil A, Koldas S (2006) Acid mine drainage (AMD): causes, treatment and case studies. J Clean Prod 14:1139-1145

Al Musawi MS, Jaafar MS, Al-Gailani B, Ahmed NM, Suhaimi FM, Bakhsh M (2016) Erythrocyte sedimentation rate of human blood exposed to low-level laser. Lasers Med Sci 31:1195-1201

Antonowicz JP, Kubiak J, Machula S (2016) Macroelements in the surface microlayer of water of urban ponds. Limnol Rev 16:115-120

Ayala A, Muñoz MF, Argüelles S (2014) Lipid peroxidation: production, metabolism, and signaling mechanisms of malondialdehyde and 4hydroxy-2-nonenal. Oxidative Med Cell Longev 2014:360438

Berkun M (2005) Submarine tailings placement by a copper mine in the deep anoxic zone of the Black Sea. Water Res 39:5005-5016

Brigden M (1998) The erythrocyte sedimentation rate. Still a helpful test when used judiciously. Postgrad Med 103(257-262):272-274

Brigden ML (1999) Clinical utility of the erythrocyte sedimentation rate. Am Fam Physician 60:1443-1450

Burcham PC (1998) Genotoxic lipid peroxidation products: their DNA damaging properties and role in formation of endogenous DNA adducts. Mutagenesis 13:287-305

Casiot C, Morin G, Juillot F, Bruneel O, Personné JC, Leblanc M, Duquesne K, Bonnefoy V, Elbaz-Poulichet F (2003) Bacterial immobilization and oxidation of arsenic in acid mine drainage (Carnoulès creek, France). Water Res 37:2929-2936

Courtney R (2013) Mine tailings composition in a historic site: implications for ecological restoration. Environ Geochem Health 35:79-88

Dold B (2008) Sustainability in metal mining: from exploration, over processing to mine waste management. Rev Environ Sci Biotechnol 7:275-285

Duma S (1998) Studiul geoecologic al exploatărilor miniere din zona sudică a Muntilor Apuseni, Muntilor Poiana Ruscă si Muntii Sebesului. Ed Dacia, Cluj-Napoca 379 p

Elshkaki A, Graedel TE, Luca C, Reck BK (2016) Copper demand, supply, and associated energy use to 2050. Glob Environ Chang 39:305-315

Fabry TL (1987) Mechanism of erythrocyte aggregation and sedimentation. Blood 70:1572-1576

Fall M, Celestin JC, Pokharel M, Touré M (2010) A contribution to understanding the effect of curing temperature on the mechanical properties of cemented tailings. Eng Geol 114:397-413

Håkanson L (1981) A manual of lake morphometry. Springer-Verlag, Berlin 78 pp

Halliwell S, Gutteridge JMC (2007) Free radicals in biology and medicine, 4th edn. Oxford University Press, New York

ISO 14403-2 (2012) Water quality - determination of total cyanide and free cyanide using flow analysis (FIA and CFA) - part 2: method using continuous flow analysis (CFA). ISO 2012. https://www.iso. org/standard/52208.html. Accessed 17 Jan 2017

Jitar O, Teodosiu C, Oros A, Plavan G, Nicoara M (2015) Bioaccumulation of heavy metals in marine organisms from the Romanian sector of the Black Sea. New Biotechnol 32:369-378

Karlsson S, Sandén P, Allard B (1987) Environmental impacts of an old mine tailings deposit - metal adsorption by particulate matter. Nordic Hydrol 18:313-324

Koçak M, Akçil E (2006) The effects of chronic cadmium toxicity on the hemostatic system. Pathophysiol Haemost Thromb 35:411-416

Komosa A, Rzymski P, Perek B, Ropacka-Lesiak M, Lesiak M, SillerMatula JM, Poniedziałek B, (2017) Platelets redox balance assessment: current evidence and methodological considerations. Vascul Pharmacol 93-95:6-13

Krewski D, Yokel RA, Nieboer E, Borchelt D, Cohen J, Harry J, Kacew S, Lindsay J, Mahfouz AM, Rondeau V (2007) Human health risk assessment for aluminium, aluminium oxide, and aluminium hydroxide. J Toxicol Environ Health B Crit Rev 10(Suppl 1):1-269

Levei E, Frentiu T, Ponta M, Tanaselia C, Borodi G (2013) Characterization and assessment of potential environmental risk of tailings stored in seven impoundments in the Aries river basin, Western Romania. Chem Cent J 7:5

Lillicrap D, Key N, Makris M, O'Shaughnessy D (2009) Practical hemostasis and thrombosis. Wiley-Blackwell, London

Melenti IL, Magyar E, Rusu T (2011) Heavy metal analysis in waste water samples from Valea Șesei tailing pond. Conference Aerul Și Apa, Book of abstracts, Cluj. http://aerapa.conference.ubbcluj.ro/ 2011/PDF/LauraMelentiMagyar.pdf. Accessed 17 Jan 2017

Migaszewski ZM, Gałuszka A, Migaszewski A (2014) The study of rare earth elements in farmer's well waters of the Podwiśniówka acid mine drainage area (south-central Poland). Environ Monit Assess 186:1609-1622

Migaszewski ZM, Gałuszka A, Dołegowska S (2016) Rare earth and trace element signatures for assessing an impact of rock mining and processing on the environment: Wiśniówka case study, southcentral Poland. Environ Sci Pollut Res Int. doi:10.1007/s11356-016$7713-\mathrm{y}$

Milu V, Leroy JL, Peiffert C (2002) Water contamination downstream from a copper mine in the Apuseni Mountains, Romania. Environ Geol 42:773-782

Milu V, Milesi JP, Leroy JL (2004) Rosia Poieni copper deposit, Apuseni Mountains, Romania: advanced argillic overprint of a porphyry system. Mineral Deposita 39:173-188

Mleczek M, Rutkowski P, Niedzielski P, Goliński P, Gąsecka M, Kozubik T, Dąbrowski J, Budzyńska S, Pakuła J (2016) The role of selected tree species in industrial sewage sludge/flotation tailing management. Int J Phytorem 18:1086-1095

Moncur MC, Ptacek CJ, Blowes DW, Jambor JL (2005) Release, transport and attenuation of metals from an old tailings impoundment. Appl Geochem 20(3):639-659

Müller B, Axelsson MD, Ohlander B (2002) Adsorption of trace elements on pyrite surfaces in sulfidic mine tailings from Kristineberg (Sweden) a few years after remediation. Sci Total Environ 298:1-16

Nathan C (2006) Neutrophils and immunity: challenges and opportunities. Nat Rev Immunol 6(3):173-182

Palta S, Saroa R, Palta A (2014) Overview of the coagulation system. Indian J Anaesth 58:515-523

Parsi K, Exner T, Connor DE, Ma DD, Joseph JE (2007) In vitro effects of detergent sclerosants on coagulation, platelets and microparticles. Eur J Vasc Endovasc Surg 34:731-740

Pizon AF, Jang DH, Wang HE (2011) The in vitro effect of Nacetylcysteine on prothrombin time in plasma samples from healthy subjects. Acad Emerg Med 18:351-354

Plavan G, Jitar O, Teodosiu C, Nicoara M, Micu D, Strungaru SA (2017) Toxic metals in tissues of fishes from the Black Sea and associated 
human health risk exposure. Environ Sci Pollut Res Int 24:77767787

Poniedziałek B, Rzymski P, Karczewski J (2014) Cylindrospermopsin decreases the oxidative burst capacity of human neutrophils. Toxicon 87:113-119

Poniedziałek B, Rzymski P, Karczewski J (2015a) The role of the enzymatic antioxidant system in cylindrospermopsin-induced toxicity in human lymphocytes. Toxicol in Vitro 29:926-932

Poniedziałek B, Rzymski P, Kokociński M, Karczewski J (2015b) Toxic potencies of metabolite(s) of non-cylindrospermopsin producing Cylindrospermopsis raciborskii isolated from temperate zone in human white cells. Chemosphere 120:608-614

Rico M, Benito G, Salgueiro AR, Díez-Herrero A, Pereira HG (2008) Reported tailings dam failures. A review of the European incidents in the worldwide context. J Hazard Mater 152:846-852

Rosenmund A, Haeberli A, Straub PW (1984) Blood coagulation and acute iron toxicity. Reversible iron-induced inactivation of serine proteases in vitro. J Lab Clin Med 103:524-533

Rzymski P, Niedzielski P, Klimaszyk P, Poniedziałek B (2014) Bioaccumulation of selected metals in bivalves (Unionidae) and Phragmites australis inhabiting a municipal water reservoir. Environ Monit Assess 186:3199-3212

Rzymski P, Niedzielski P, Kaczmarek N, Jurczak T, Klimaszyk P (2015) The multidisciplinary approach to safety and toxicity assessment of microalgae-based food supplements following clinical cases of poisoning. Harmful Algae 46:34-42

Rzymski P, Poniedziałek B, Mankiewicz-Boczek J, Faassen EJ, Jurczak T, Gagała I, Ballot A, Lürling M, Kokociński M (2017) Polyphasic toxicological screening of Cylindrospermopsis raciborskii and Aphanizomenon gracile isolated in Poland. Algal Res 24:72-80

Stefănescu L, Robu BM, Ozunu A (2013) Integrated approach of environmental impact and risk assessment of Rosia Montana mining area, Romania. Environ Sci Pollut Res Int 20:7719-7127

Strungaru SA, Nicoara M, Jitar O, Plavan G (2015) Influence of urban activity in modifying water parameters, concentration and uptake of heavy metals in Typha latifolia L. into a river that crosses an industrial city. J Environ Health Sci Eng 13:5

Stumbea D (2013) Preliminaries on pollution risk factors related to mining and ore processing in the Cu-rich pollymetallic belt of Eastern Carpathians, Romania. Environ Sci Pollut Res Int 20:7643-7655

Vick SG (1990) Planning, design, and analysis of tailings dams. BiTech Publishers, Vancouver

Wang P, Liu Y, Menzies NW, Wehr JB, de Jonge MD, Howard DL, Kopittke PM, Huang L (2016) Ferric minerals and organic matter change arsenic speciation in copper mine tailings. Environ Pollut 218:835-843

Wills BA, Napier-Munn T (2006) Wills' mineral processing technology (Seventh Edition). An introduction to the practical aspects of ore treatment and mineral recovery. Elsevier, Amsterdam

Zegura B, Heath E, Cernosa A, Filipic M (2009) Combination of in vitro bioassays for the determination of cytotoxic and genotoxic potential of wastewater, surface water and drinking water samples. Chemosphere 75:1453-1460

Zhang M (2011) Adsorption study of Pb(II), Cu(II) and Zn(II) from simulated acid mine drainage using dairy manure compost. Chem Eng J 49:827-837 